\title{
Prevalence of Cryptosporidia, Eimeria, Giardia, and Strongyloides in pre-weaned calves on smallholder dairy farms in Mukurwe-ini district, Kenya
}

\author{
Getrude Shepelo Peter ${ }^{1}$, George Karuoya Gitau ${ }^{1}$, Charles Matiku Mulei ${ }^{1}$, John Vanleeuwen², Shauna Richards ${ }^{2}$, \\ Jeff Wichtel ${ }^{2}$, Fabienne Uehlinger ${ }^{3}$, and Omwando Mainga ${ }^{4}$ \\ 1. Department of Clinical Studies, Faculty of Veterinary Medicine, University of Nairobi, P.O. Box 29053-00625, Kangemi, \\ Kenya; 2. Department of Health Management, Centre for Veterinary Epidemiological Research, Atlantic Veterinary \\ College, University of Prince Edward Island, 550 University Avenue, Charlottetown PEI Canada, C1A 4P3; 3. Department \\ of Large Animal Clinical Sciences, Western College of Veterinary Medicine, University of Saskatchewan, 52 Campus Drive, \\ Saskatoon SK Canada, S7N 5B4, Canada; 4. Department of Public Health, Pharmacology, and Toxicology, Faculty of \\ Veterinary Medicine, University of Nairobi, P.O. Box 29053-00625, Kangemi, Kenya. \\ Corresponding author: Getrude Shepelo Peter, e-mail: shepelog@gmail.com, GK: gkgitau@uonbi.ac.ke, \\ CM: cmulei@uonbi.ac.ke, JV: jvanleeuwen@upei.ca, SR: srichards@upei.ca, JW: jwichtel@upei.ca, \\ FU: f.uehlinger@usask.ca, MO: alfredomwando@gmail.com \\ Received: 07-04-2015, Revised: 16-08-2015, Accepted: 23-08-2015, Published online: 22-09-2015
}

doi: 10.14202/vetworld.2015.1118-1125 How to cite this article: Peter SG, Gitau GK, Mulei CM, Vanleeuwen J, Richards S, Wichtel J, Uehlinger F, Mainga O (2015) Prevalence of Cryptosporidia, Eimeria, Giardia, and Strongyloides in pre-weaned calves on smallholder dairy farms in Mukurwe-ini district, Kenya, Veterinary World 8(9): 1118-1125.

\begin{abstract}
Aim: Gastrointestinal diseases are among the leading causes of calf morbidity and mortality in Kenya and elsewhere. This study was undertaken to determine the prevalence of Cryptosporidia, Eimeria, Giardia, and Strongyloides in calves on smallholder dairy farms (SDF) in Mukurwe-ini District, Nyeri County, Kenya. These infections have been associated with economic losses by decreased growth rates, decreased productivity, and increased susceptibility to other diseases.

Materials and Methods: An observational study was conducted on 109 farms in Mukurwe-ini District, Nyeri County, Kenya, where 220 calf fecal samples (each calf at 4 and 6 weeks of age) from 110 calves ( 1 set of twins) were collected and analyzed for Cryptosporidia, Eimeria, Giardia, and helminth parasites.

Results: Eimeria oocysts, Cryptosporidia oocysts, and Strongyloides eggs were detected in the fecal samples examined, but no Giardia cysts were found. The overall period prevalence of Eimeria, Cryptosporidia, and Strongyloides was 42.7\% (47/110), 13.6\% (15/110), and 5.4\% (6/110), respectively. The prevalence at 4 weeks of age for Eimeria, Cryptosporidia, and Strongyloides was 30.0\% (33/110), 8.2\% (9/110), and 3.7\% (4/109), respectively, while the prevalence at 6 weeks of age was $20.2 \%(22 / 109), 6.5 \%(7 / 107)$, and $2.7 \%(3 / 110)$, respectively. There was, however, no significant difference in the prevalence at 4 and 6 weeks $(\mathrm{p}>0.05)$.
\end{abstract}

Conclusion: Findings from this study show that Eimeria, Cryptosporidia, and Strongyloides, are prevalent in the study area and indicate the need to adopt optimal management practices to control infections in calves.

Keywords: Cryptosporidia, Eimeria, Giardia, pre-weaned calves, smallholder dairy farms, Strongyloides.

\section{Introduction}

Gastrointestinal (GI) and respiratory diseases are the leading causes of calf morbidity and mortality in Kenya and Elsewhere [1-3]. GI diseases in calves can be caused by protozoa such as Cryptosporidium, Coccidia, and Giardia; bacteria such as Escherichia coli; and viruses such as rotavirus and coronavirus [4,5]. Cryptosporidia, Coccidia, and Giardia have been associated with both clinical and sub-clinical disease in calves, resulting in great economic losses by decreased growth rates, decreased productivity, and increased susceptibility to other diseases [6-8]. GI nematode infections in cattle are widespread in the world [9], including herds in Kenya [8], causing constraints to productivity through decreased growth rates and mortalities.

Copyright: The authors. This article is an open access article licensed under the terms of the Creative Commons Attributin License (http:// creativecommons.org/licenses/by/2.0) which permits unrestricted use, distribution and reproduction in any medium, provided the work is properly cited.
Cryptosporidia is considered as one of the most common causes of neonatal diarrhea in dairy herds $[10,11]$. There are a number of species of Cryptosporidium that infect cattle, and these include Cryptosporidium parvum, Cryptosporidium ryanae, Cryptosporidium andersoni, and Cryptosporidium hominis [12]. Cryptosporidium parvum is the most common of the species, commonly found in young calves, and together with $C$. hominis, they have zoonotic potential. Young calves are therefore a source of infection to humans [13-15]. In Africa, the prevalence of Cryptosporidia among the pre-weaned dairy calves varied from $16.5 \%$ in Mogogoro Tanzania [16] and $18 \%$ in Kenya [17] to $34 \%$ in Zambia [18]. Bovine eimeriosis is mainly an infection of young animals $[8,19]$. Most Coccidia species are host specific, and the most pathogenic in cattle are Eimeria bovis and Eimeria zuernii [8,20,21]. In Kenya, a prevalence of $69.3 \%$ in calves has been reported by Waruiru et al. [8], and the following prevalences have been reported elsewhere in the 
developing world: $52 \%$ in South Africa [22], 48\% in Argentina [23], 50\% in India [24], and 51.8\% in China [25]. Giardiasis is a common protozoal disease of cattle, especially calves [26]. Giardia duodenalis is the species reported to infect humans and a wide range of mammalian species [27]. Giardia duodenalis has seven assemblages which have host preferences, and assemblage $\mathrm{E}$ is known to infect livestock $[6,28,29]$. There is also evidence that the species that affect animals also affect human beings [30-32]. The greatest risk of zoonotic transmission seems to come from dogs and cats [33] and dairy cattle [34] who act as reservoirs. The major GI nematodes are Haemonchus, Trichostrongylus, Cooperia, and Oesophagostomum [35]. Strongyloides is a minor nematode species, but can cause sudden death without any clinical signs in young calves due to hyperinfection with larvae [36]. Pre-weaned calves typically only get exposed to Strongyloides prior to consuming grass. The prevalence of Strongyloides has been reported on smallholder farms in the following African countries: $7 \%$ in Ethiopia [37]; $4.0 \%$ in Kiambu District in Kenya [8]; and 2-5\% in Nyandarua District in Kenya [38].

Prevention remains a very critical intervention in the management of calf diseases, especially of the GI tract (GIT). This study was therefore undertaken to determine the prevalence of Cryptosporidia, Eimeria, Giardia, and Strongyloides in order to guide efforts needed to control them through better management. Additionally, many calves in smallholder dairy farms (SDF) are hand-fed, making it important to survey the prevalence of Cryptosporidia and Giardia which have zoonotic potential [15].

\section{Materials and Methods}

\section{Ethical approval}

The study was approved by Biosecurity, Animal use and Ethics committee, Faculty of Veterinary Medicine, University of Nairobi. The farmers were recruited into the study, signed a consent form.

\section{Study area}

The study was carried out in Mukurwe-ini District, Nyeri County, Kenya. Nyeri County is one of the 47 counties in Kenya, and one of the five counties of the former central province. It is part of Kenya's Central Highlands. Nyeri County is located between longitude $36^{\circ}$ and $38^{\circ}$ east and between the equator and latitude $1^{\circ}$ south. Mount Kenya is located to the east of Nyeri County at an altitude of $5199 \mathrm{~m}$, and the Aberdare Range is to the west at $3999 \mathrm{~m}$ [39]. Nyeri County is part of Kenya's Central Highlands and is sub-divided into seven Districts: Othaya, Mukurwe-ini, Mathira, Kieni East, Kieni West, Municipality, and Tetu. Mukurwe-ini District covers an area of $180.5 \mathrm{~km}^{2}$ with a population of 87,447 persons [40]. It is located $1644 \mathrm{~m}$ above sea level. The District has four divisions and is gazetted as; Mukurwe-ini West (Gakindu), Mukurwe-ini East (Giathugu and Rutune), Mukurwe-ini Central (Muhito and Githi), and Mukurwe-ini North (Gikondi and Thanu) [41].

The topography of the study area is characterized by steep ridges and valleys, especially the southern part of Mukurwe-ini. In addition to the fertile soils, the study area receives adequate equatorial rainfall, making it suitable for the crop (coffee and tea farming) and dairy farming. Dairy farming is mainly done on smallholder farms where zero-grazing is practiced. In these units, farmers cut fodder either from their farms or roadsides and take it to the cattle [42].

\section{Farm and calf selection and study design}

Dairy farms used in this study were selected from Mukurwe-ini Wakulima Dairy Limited (MWDL), which has approximately 6,000 active members. Purposive sampling was used to select smallholder farms (i.e., having up to 4 cows) to be included in the study. Artificial insemination records kept by the dairy company were queried to identify farms with dams that were due to calf in the months of June and July 2013 (rainy season in Kenya). The farms whose records indicated that they had a cow that was to calve within the study period were contacted by phone and invited to participate in the study. In order to be included, farmers had to agree to keep the calf for at least the first 6 weeks of its life (the study period). When a farmer agreed to participate in the study, he/she was requested to contact MWDL as soon as the cow calved. A total of 109 farms were selected into the study with a total number of 110 calves (one farm had twins).

The farms were first visited within a week of the calf being born. Each of the study calves was allocated a study number and ear tagged for identification. Subsequent visits were made at 4 and 6 weeks of age for fecal sampling.

\section{Fecal sample collection}

Two fecal samples were rectally collected from each calf; one at 4 weeks and the second one at 6 weeks of age. The samples were labeled and placed in fecal bottles and transported in a cool box to the laboratory for analysis. In the laboratory, analysis of Eimeria, Cryptosporidia, Giardia parasites, and helminth eggs was done as described in the next section.

\section{Fecal parasite analysis}

Analysis of Cryptosporidia, Eimeria, Strongyloides, and Giardia

Sheather's sucrose floatation method was used to harvest the Cryptosporidium oocysts, and slides were subsequently stained using modified Ziehl-Neelsen stain as described by Pfukenyi et al. [43]. On observation of the slide under a light microscope at $\times 100$ oil immersion, the oocysts stained red with varying 
degrees of intensity against a green background, whereas the most fecal debris and yeast cells take up the color of the counterstain (Malachite green). One slide per sample was analyzed. The samples were considered positive if at least one morphologically distinct Cryptosporidium oocyst was observed (round to oval oocyst and at times a black dot or small vacuoles in oocyst could be seen).

The McMaster technique was used for determining the number of nematode eggs and Eimeria oocysts per gram of feces [44]. Both compartments of the McMaster counting chamber were filled with the sub-sample then allowed to stand for $5 \mathrm{~min}$, before being examined under a light microscope $(\times 100)$ and all eggs and Eimeria oocysts within the engraved area of the chamber were counted. The number of eggs per gram (EPG) was calculated as the number of eggs within the grid of each chamber multiplied by a factor of 50 [44]. Strongyloides papillosus eggs were identified by the characteristic sphere-shaped egg with a thin wall, flattened edges and with a larva inside. Strongyloides was reported when EPG was $\geq 200$ since this was considered as moderate to high infection [45]. The presence of any coccidian oocysts was defined as infected.

The formol-ether parasite concentration technique was used to harvest Giardia cysts, as described by Cheesbrough [46]. The sediment content was placed on a microscope slide and examined under the light microscope at $\times 100$ magnification. The presence of one Giardia cyst in a sample was reported as an infection.

\section{Data analysis}

The laboratory results were manually entered into an excel spreadsheet [47]. The data were then imported to SPSS for windows, Version 20. Prevalence of the infections was made based on detection of Cryptosporidia and Eimeria oocysts or Giardia cysts in at least one of the examined fecal samples for each calf, and Strongyloides eggs (EPG $\geq 200$ ). Chi-square was used to calculate the $p$-value to determine the difference in prevalence of the parasites at 4 and 6 weeks of age.

\section{Results}

There were 110 calves enrolled in the study (48 females and 62 males), with a total of 220 fecal samples collected from the 109 farms (including the farm with twins). The results of the fecal examinations revealed Eimeria and Cryptosporidia as the protozoal infections infecting the calves, and Strongyloides as the helminth infection present among the study calves. There were no Giardia cysts detected in the fecal samples of the calves. Figure-1 shows a Cryptosporidia oocyst staining pink against a green malachite background. Figures-2 and -3 show an Eimeria oocyst and a Strongyloides papillosus egg as they appeared under a light microscope, respectively.
Table-1 shows the prevalence of Eimeria, Cryptosporidia, and Strongyloides infections among the study calves. There were no Giardia cysts detected in the fecal samples of the calves. Among the three parasites, Eimeria had the highest prevalence and Strongyloides was the least prevalent. Overall, a total of $52.7 \%(58 / 110)$ of the calves were infected with at least one of the parasites for at least one test

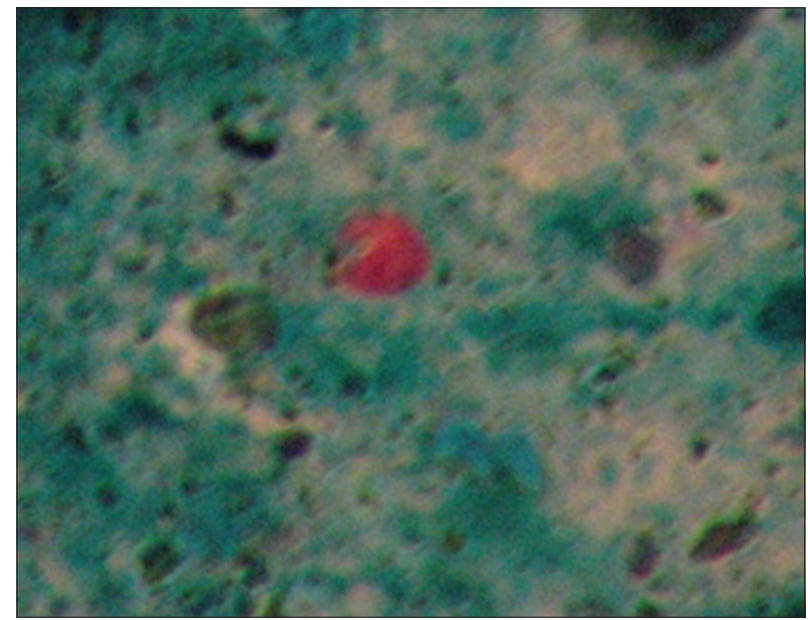

Figure-1: Cryptosporidium oocyst after staining with Modified Ziehl-Neelsen $(\times 1000)$.

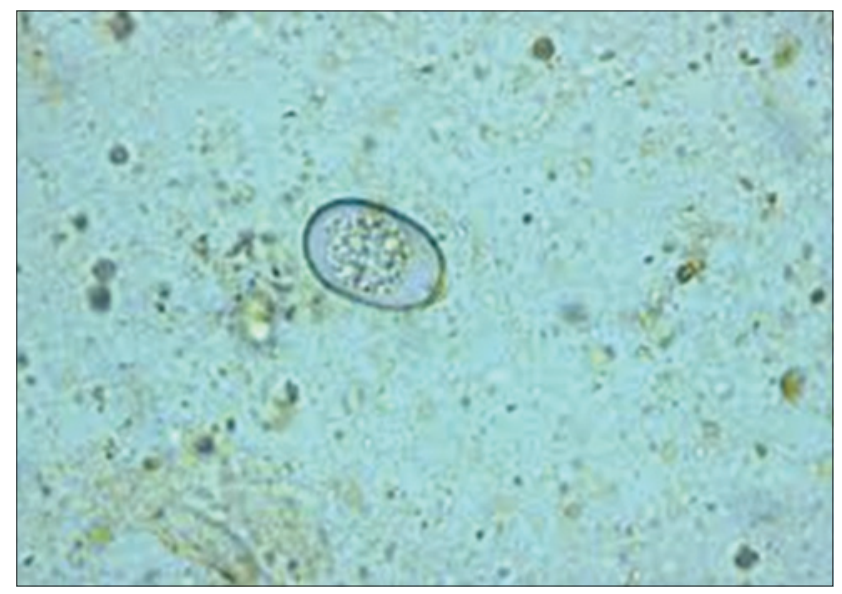

Figure-2: Eimeria oocyst as seen under a microscope (Sporozoite inside) $(\times 100)$

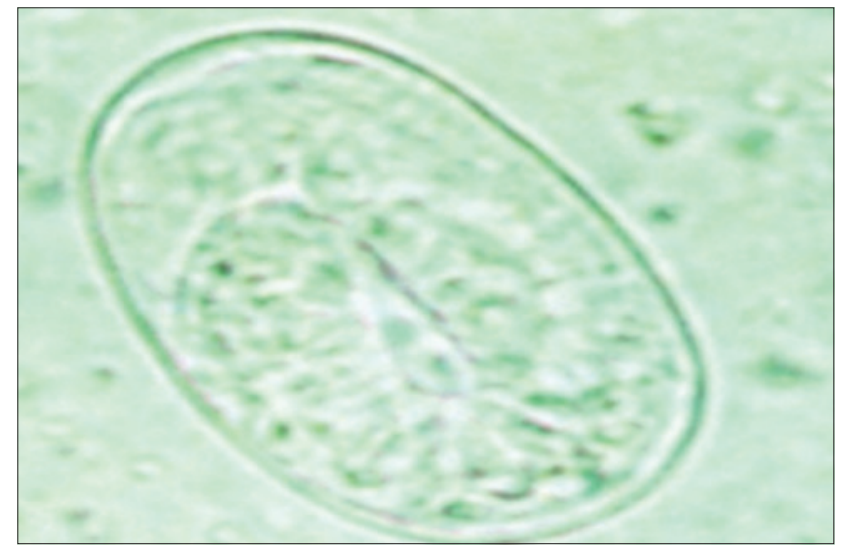

Figure-3: Strongyloides papillosus egg with larva inside $(\times 400)$. 
Table-1: Prevalences of Eimeria, Cryptosporidia, and Strongyloides in 110 calves reared in 109 smallholder dairy farms in Mukurwe-ini District, Kenya, 2013.

\begin{tabular}{|c|c|c|c|c|c|c|c|c|}
\hline \multirow{3}{*}{$\begin{array}{l}\text { Parasitic } \\
\text { condition }\end{array}$} & \multicolumn{8}{|c|}{ Prevalence } \\
\hline & \multicolumn{2}{|c|}{4 weeks } & \multicolumn{2}{|c|}{6 weeks } & \multicolumn{2}{|c|}{ At 4 and 6 weeks } & \multicolumn{2}{|c|}{ At 6 or 4 weeks } \\
\hline & $\%$ & 95\% CI & $\%$ & $95 \%$ CI & $\%$ & $95 \%$ CI & $\%$ & 95\% CI \\
\hline Eimeria & $30.0(33 / 110)$ & $(21.8-39.6)$ & $20.2(22 / 109)$ & $(13.3-29.2)$ & $7.3(8 / 109)$ & $(3.5-14.4)$ & $42.7(47 / 110)$ & $(33.5-52.5)$ \\
\hline Cryptosporidia & $8.2(9 / 110)$ & $(4.0-15.4)$ & $6.5 \%(7 / 107)$ & $(2.9-13.5)$ & $0.9(1 / 107)$ & $(0.1-5.8)$ & $13.6(15 / 110)$ & $(8.1-21.8)$ \\
\hline Strongyloides & $3.7(4 / 109)$ & $(1.2-9.7)$ & $2.7 \%(3 / 110)$ & $(0.7-8.4)$ & $0.9(1 / 109)$ & $(0.1-5.8)$ & $5.4(6 / 110)$ & $(2.2-12.0)$ \\
\hline
\end{tabular}

CI: Confidence interval

sample, with $37.3 \%(41 / 110)$ infected at 4 weeks and $28.2 \%(31 / 110)$ infected at 6 weeks. The prevalence of Eimeria, Cryptosporidia, and Strongyloides was numerically but not statistically significantly higher at 4 weeks than at 6 weeks of age (p-value $=0.64 ; 0.47$; 0.11 , respectively). Moreover, the confidence intervals for the two ages of calves were overlapping for the three parasites. Only $7.3 \%$ (8/109), $0.9 \%$ (1/107), and $0.9 \%(1 / 109)$ of the study calves were infected at both 4 and 6 weeks of age with Eimeria, Cryptosporidia, and Strongyloides, respectively.

Mixed parasitic infections were reported in $10.3 \%(6 / 58)$ and were only detected in 4 week old calves; Eimeria and Cryptosporidia 5.2\% (3/58), Eimeria and Strongyloides 3.4\% (2/58), Eimeria, Cryptosporidia, and Strongyloides 1.7\% (1/58). All mixed infections occurred with Eimeria and one or more of the other parasites.

\section{Discussion}

Our study showed the presence of Eimeria oocysts, Cryptosporidia oocysts, and Strongyloides eggs in 4 and 6 weeks old dairy calves. Their prevalences were higher at 4 weeks of age compared to 6 weeks of age for all parasites. Calves are born immunologically naïve (immature immunity) [48] and their immunity matures with time, therefore calves at 6 weeks of age are able to mount a higher primary immune response than at 4 weeks of age [49]. Therefore, the development of some immunity could have partially led to the slightly lower prevalences at 6 weeks. There was, however, no significant difference in the prevalence of the parasitic conditions during the two time periods. The calves at both 4 and 6 weeks are still pre-weaned, hence mainly feeding on milk and small amounts of forage and calf pellets. Therefore, the sources of infection were likely similar. Mixed infections were only reported at 4 weeks, possibly due to the active immunity that is more pronounced at 6 weeks, hence reducing the number of overall infections and thus mixed infections as well.

Cryptosporidium species were detected in the study calves and the common species affecting calves have been known to have zoonotic potential [50,51]. Young calves are therefore a source of infection to human beings [13-15], especially in smallholder systems where hand-feeding is common [52]. Disadvantaged communities, such as rural areas where poverty levels are high, experience a greater impact of cryptosporidiosis which commonly has co-infections with other GI parasites [12,53].

Eimeriosis has been reported to be a common disease of calves [8,54-56], especially if they are kept in confinement $[54,57]$. Our study shows the overall infection prevalence of the calves at 4 or 6 weeks by Eimeria was $42.7 \%$. This prevalence is lower than previous reports in Kenya of $67.4 \%$ by [58] and other reports in Ethiopia, [54] (68.1\%) and (47.1\%) in China [25].

Conversely, our prevalence was higher than reports in other regions: $19.8 \%$ in Zimbabwe [45], $22.7 \%$ [59] and $31.9 \%$ [60] in Ethiopia; $22.5 \%$ in Turkey [61], and 27.2\% in Pakistan [57]. The wide prevalence variations may be associated with the differences in agroecology, farm management and husbandry in the different countries, the epidemiological status of Eimeria on the study farms and/or diagnostic tests used in the areas. Although Eimeria parasites were isolated from our study animals, there was no clinical disease observed on the biweekly visits. This finding suggests that most Eimeria infections in these calves were mild or sub-clinical and were more likely important in causing negative calf performance than clinical disease [57]. Eimeria oocysts were common among the calves, because of the ubiquitous nature of the oocysts on many farms [62]. Most farmers in the study area keep calves in confinement, and this has been reported to cause build-up of the hardy environmental oocysts [56], especially if hygiene is poor, hence increasing infection [59].

Cryptosporidium species have been reported in several species of young animals including bovine calves [63]. Transmission of the parasite is by the fecal-oral route, and the disease is readily transmissible since the oocysts persist for long periods in suitable environments [64], and very low numbers are required for infection to occur [65]. There was evidence that young calves (up to 6 weeks) from Mukurwe-ini District were infected by Cryptosporidia, and there is a need for strict adherence to good husbandry practices and hygiene. The overall prevalence of Cryptosporidia in the study calves during the study period was $13.6 \%$. 
The prevalence was similar to other reports of $18 \%$ in Kenya [17], $13.2 \%$ in Turkey [61], and $17.1 \%$ in Argentina [63], but higher than the $3.1 \%$ found in beef calves in Canada [66].

Our Cryptosporidium prevalence was however lower than reports in other parts of Africa, although the studies in Africa are limited: $27 \%$ in Tanzania [11]; 38\% in Uganda [67], 26.1\% in Algeria [68], and $86.7 \%$ in Tunisia [69]. Other parts of the world have also reported a higher prevalence than the one reported in our study: $27 \%$ in Mexico [70], and $27 \%$ and $30 \%$ in Ontario, Canada $[71,72]$, possibly due to the use of highly sensitive techniques such as ELISA and polymerase chain reaction. The apparent variability of prevalence between geographical localities and reports may reflect differences in the levels of calf management practices employed at the farm level, housing-related factors (i.e., single housed calves, cleanliness of the calf sleeping places), calf-related factors at the time of sampling (diarrheic versus non-diarrheic), nature of the study (cross-sectional versus longitudinal studies), and fecal screening technique used [73]. The prevalence was higher at 1 month than at $1 \frac{1 / 2}{2}$ months, and this agrees with other findings [74-76] that Cryptosporidium is common in calves up to 1 month of age.

Strongyloides was the main helminth infection reported in our calves up to 6 weeks of age. It has been detected as early as 2 weeks of age $[77,78]$, and this has been associated with the immature immunity of calves. In our study, the prevalence of Strongyloides papillosus at 4 and/or 6 weeks of age was 5.4\%, however, there were no strongyle eggs found. Our Strongyloides prevalence was lower than that reported $(34.5 \%)$ in Serbia [77], and in Mali (39\%) [48], but higher than the $2.0 \%$ in Zimbabwe [45], $4.0 \%$ in Kenya [8], and $4.3 \%$ in Czech Republic [36]. Contrary to Strongyloides, strongyles have been reported in calves more than 4 months of age [77] since at this age, there is increased forage ingestion, hence greater likelihood of ingesting the infective stages of the parasite. Strongyloides papillosus seems to infect mainly calves with its excretion diminishing by 6-8 months of age $[45,79]$. Excretion of Strongyloides eggs has been reported to be positively correlated to excretion by the dam, which is linked to vertical transmission of this parasite [48].

A relatively high prevalence of Giardia cysts has been detected in dairy calves elsewhere, with the cysts being detected in dairy calves as early as 1 month of age $[30,74,80,81]$. However, in our study, there were no Giardia cysts detected. This is contrary to other studies that reported existence of this protozoan, especially in dairy calves of similar age as the study calves; $14.7 \%$ [68] in Algeria; calves of 5-week-old, a prevalence of $44 \%$ in Myanmar was reported [30]; $85 \%$ in beef calves in the USA [82], and an overall prevalence of $32.5 \%$ in 6-week-old calves in Azerbaijan [83].
Giardia tends to be a chronic infection in calves; hence calves older than 8 weeks continue to be infected [72]. It is speculated that this protozoan may be absent in SDF in the study area since no previous literature has documented its prevalence in the study area. The absence of Giardia in calves may also be because of the limited water intake of the study calves in this area, and/or the water may not have been contaminated with Giardia because many farmers used water from wells or rainwater from cisterns.

\section{Conclusions and Recommendations}

This study has shown that Eimeria, Cryptosporidia, and Strongyloides in calves are prevalent among SDF in the study area; hence the importance to place control measures against these conditions as early as 1 month of age. Although the overall prevalence, and a number of multiple and mixed infections appeared to be higher at 4 weeks than 6 weeks, this difference was not statistically significant. Eimeria infection in calves seems to have a higher prevalence than the other parasites, hence the need to improve farm husbandry practices to reduce exposure to infective oocysts.

Cryptosporidium infection of calves within the first 2 months of age has been reported to be by C. parvum which is zoonotic [84]. There is, therefore, a need to characterize the Cryptosporidium species in the study area so that the zoonotic potential can be assessed. Additionally, more sensitive techniques (PCR or ELISA) need to be used for detection of Cryptosporidium species in these calves to reduce false negative results. Characterization of the Eimeria species to assess the prevalence of pathogenic species (E. bovis and E. zuernii) among the calves present in our study area would also be helpful. Further investigations of Giardia cysts, using a larger sample size of calves that are older needs to be undertaken.

\section{Authors' Contributions}

GS, SR, and JV conducted the field data collection. GS and GKG wrote the draft manuscript. All authors were involved in the preparation of data collection materials, and the revision and approval of the final manuscript. SR, JV, GKG, and JW were involved in funding acquisition. GS, SR, JV, GKG, JW, FU, $\mathrm{CMM}$, and $\mathrm{OM}$ were all involved in formulating the study design and methods of implementation of the study.

\section{Acknowledgments}

This research work was supported by: The Atlantic Veterinary College - University of Prince Edward Island, Farmers Helping Farmers, Veterinarians Without Borders-Canada, the Association of Universities and Colleges of Canada, the World Agroforestry Centre (especially Steven Franzel), and the University of Nairobi. The authors would like to appreciate the support given by Gen Luka and Jessie 
Wilkins during the field work. Special thanks also go to the leadership of Mukurwe-ini Wakulima Dairy Limited for their assistance in identifying the farms and to the farmers for their great cooperation.

\section{Competing Interests} interests.

The authors declare that they have no competing

\section{References}

1. Gitau, G.K., Aleri, J.W., Mbuthia, P.G. and Mulei, C.M. (2010) Causes of calf mortality in peri-urban area of Nairobi, Kenya. Trop. Anim. Health Prod., 42(8): 1643-1647.

2. Achá, S.J., Kühn, I., Jonsson, P., Mbazima, G., Katouli, M. and Möllby, R. (2004) Studies on calf diarrhea in Mozambique: Prevalence of bacterial pathogens. Acta Vet. Scand., 45(1-2): 27-36.

3. Constable, P.D. (2004) Antimicrobial use in the treatment of calf diarrhea. J. Vet. Intern. Med., 18: 8-17.

4. Foster, D.M. and Smith, G.W. (2009) Pathophysiology of diarrhea in calves. Vet. Clin. N. Am. Food A., 25(1): 13-36.

5. El-Naker, Y.F.I., El-Sawalhy, A.A., Youssef, M. A. A. and Zeidan, S.M. (2007) Some studies on neonatal calf diarrhea in Egypt, causative agents and some epidemiological aspects. Bull. Anim. Health Prod. Afr., 56: 161-190.

6. Gillhuber, J., Rügamer, D., Pfister, K. and Scheuerle, M.C. (2014) Giardiosis and other enteropathogenic infections: A study on diarrhoeic calves in Southern Germany. BMC Res. Notes, 7: 112. Available from:http://www.biomedcentral.com/1756-0500/7/112.

7. Geurden, T., Claerebout, E. and Vercruysse, J. (2005) Protozoan infection causes of diarrhea in calves. Tijdschr. Diergeneeskd., 130(23): 734-737.

8. Waruiru, R.M., Kyvsgaard, N.C., Thamsborg, S.M., Nansen, P., BÖgh, H.O., Munyua, W.K. and Gathuma, J.M. (2000) The prevalence and intensity of helminth and coccidial infections in dairy cattle in Central Kenya. Vet. Res. Commun., 24: 39-53.

9. Gasbarre, L.C., Leighton, E.A. and Sonstergard, T. (2001) Role of the bovine immune system and genome in resistance to gastrointestinal nematodes. Vet. Parasitol., 98: 51-64. Available from: http://www.dx.doi.org/10.1016/S03044017(01)00423-X. Accessed on 28-07-2015.

10. Gowda,A.K.J., Rekha Hoskene, K., Puttalakshmamma, G.C. and D'Souza, P.E. (2009) Studies on the prevalence of cryptosporidiosis in bovines in organized dairy farms in and around Bangalore South India. Arch. Vet. Sci, 79(5): 461-470.

11. Swai, E.S. and Schoonman, L. (2010) Investigation into the prevalence of Cryptosporidium infection in calves among smallholder dairy and traditional herds in Tanzania. J. Vet. Intern. Med., 2010: 676451.

12. Kang'ethe, E.K., Mulinge, E.K., Skilton, R.A., Njahira, M., Monda, J.G., Nyongesa, C., Mbae, C.K. and Kamwati, S.K. (2012) Cryptosporidium species detected in calves and cattle in Dagoretti, Nairobi, Kenya. Trop. Anim. Health. Prod., Suppl 1: S25-S31

13. Stantic-Pavlinic, M., Xiao, L., Glaberman, S., Lal, A.A., Orazen, T., Rataj-Verglez, A., Logar, J. and Berce, I. (2003) Cryptosporidiosis associated with animal contact. Wien. Klin. Wochenschr., 115(3-4): 125-127.

14. Olson, M.E., O’Handley, R., Ralston, B.J., McAllister, T.A. and Thompson, R.C. (2004) Update on Cryptosporidium and Giardia infections in cattle. Trends Parasitol., 20(4): 185-191.

15. Eastwood, K., Ng, J., Durrheim, D., Massey, P., Walker, B., Armson, A. and Ryan, U. (2008) Evidence supporting zoonotic transmission of Cryptosporidium in rural New South Wales. Exp. Parasitol., 119(1): 192-195.

16. Mtambo, M.M.A., Sebatwale, J.B., Kambarage, D.M., Muhairwa, A.P., Maeda, G.E., Kusiluka, L.J.M. and
Kazwale, R.R. (1997) Prevalence of Cryptosporidium spp. oocysts in cattle and wildlife in Morogoro region, Tanzania. Prev. Vet. Med., 31(3-4): 185-190.

17. Kang'ethe, E.K., McDermott, B., M'Ibui, G.M., Randolph, T.F. and Langat, A.K. (2007) Investigation into the prevalence of bovine cryptosporidiosis among smallholder dairy households in Dagoretti division, Nairobi, Kenya. East. Afr. Med. J., 84 Suppl 11: S76-S82.

18. Siwilia, J., Phiri, I.G., Vercruysse, J., Goma, F., Gabriels, S., Claerebout, E. and Geurden, T. (2007) Asymptomatic cryptosporidiosis in Zambia dairy workers and their household members. Trans. R. Soc. Trop. Med. Hyg., 101(7): 733-734.

19. Cicek, H., Sevimli, F., Kozan, E., Köse, M., Eser, M. and Doğan, N. (2007) Prevalence of coccidia in beef cattle in western Turkey. Parasitol. Res., 101: 1239-1243.

20. Daugschies, A. and Najdrowski, M. (2005) Eimeriosis in cattle: Current understanding. J. Vet. Med. B, 45: 417-427.

21. Enermark, H.L., Dahl, J. and Enermark, J.M. (2013) Eimeriosis in Danish dairy calves - correlation between species, oocyst excretion and diarrhea. Parasitol. Res. 112 Suppl 1: 169-176.

22. Matjila, P.T. and Penzhorn, B.L. (2002) Occurrence and diversity of bovine Coccidia at three. localities in South Africa. Vet. Parasitol., 2: 93-102.

23. Sanchez, R.O., Romero, J.R. and Founroge, R.D. (2008) Dynamics of Eimeria oocyst excretion in dairy calves in the province of Buenos Aires (Argentina), during their first 2 months of age. Vet. Parasitol., 151: 133-138.

24. Harpreet, K. and Daljit, K. (2008) Prevalence of gastrointestinal parasites in domestic animals of Patiala and its adjoining areas. Vet. Parasitol., 22: 13-17.

25. Dong, H., Zhao, Q., Han, H., Jiang, L., Zhu, S., Li, T., Kong, C. and Huang, B. (2012) Prevalence of coccidial infection in dairy cattle in Shanghai, China. Vet. Parasitol., 8(5): 63-66.

26. Vercruysse, J. and Claerebout, E. (2001) Treatment versus non-treatment of helminth infections in cattle: Defining the thresholds. Vet. Parasitol., 98: 195-214.

27. Mark-Carew, M.P., Yasin, K., Susan, E.W., Stephanie, S. and Hussni, O.M. (2010) Incidence of and risks associated with Giardia infections in herds on dairy farms in the New York City Watershed. Acta Vet. Scand., 52: 44. Available from: http://www. actavetscand.com/content/52/1/44. Accessed on 02-03-2015.

28. Monis, P.T., Andrews, R.H., Mayrhofer, G. and Ey, P.L. (1999) Molecular systematics of the parasitic protozoan Giardia duodenalis. Mol. Biol. Evol., 16: 1135-1144.

29. Trout, J.M., Santrin, M., Greiner, E. and Faver, R. (2005) Prevalence and genotypes of Giardia duodenalis in postweaned dairy calves. Vet. Parasitol., 130(3-4): 177-183.

30. Khin, K.L. (2007) Prevalence of Cryptosporidium, Giardia and other gastrointestinal parasites in dairy calves in Mandalay, Myanmar. MSc Thesis, Chiang Mai University and Freie Universität Berlin.

31. Lalle, M., Pozio, E., Capelli, G., Bruschi, F., Crotti, D. and Cacciò, S.M. (2005) Genetic heterogeneity at the beta-giardin locus among human and animal isolates of Giardia duodenalis and identification of potentially zoonotic subgenotypes. Int. J. Parasitol., 35(2): 207-213.

32. Thompson, R.C. and Monis, P.T. (2012) Giardia, from genotype to proteome. Adv. Parasitol., 78: 57-95.

33. Thompson, R.C. (2004) The zoonotic significance and molecular epidemiology of Giardia and giardiasis. Vet. Parasitol., 126(1-2): 15-35.

34. Thompson, R.C. (2000) Giardiasis as a re-emerging infectious disease and its zoonotic potential. Int. J. Parasitol., 30(12-13): 1259-1267.

35. Maingi, N. and Gichigi, M.N. (1992) Gastrointestinal nematodes in cattle on four farms in Nyandarua District. Bull. Anim. Health Prod. Afr., 40: 9-10.

36. Kváč, L. and Vitovec, J. (2007) Occurrence of Strongyloides papillosus associated with extensive pulmonary lesions and sudden deaths in calves on a beef farm in a highland 
area of South Bohemia (Czech Republic). Helminthologia, 44(1): 10-13.

37. Degefe, H., Abera, C., Yohannes, M. and Tolosa, T. (2011) Gastrointestinal helminth infections in small-scale dairy cattle farms of Jimma town, Ethiopia. Ethiop. J. Sci. Technol., 2(1): 31-37

38. Maingi, N. and Njoroge, G.K. (2010) Constraints on production, disease perceptions and ticks and helminths control practices on dairy cattle farms in Nyandarua District, Kenya. Livest. Res. Rural Dev., 22,(8):138. http://www.lrrd. org/lrrd22/8/main22138.htm, Accessed on 30-03-2015.

39. Richards, S., VanLeeuwen, J., Shepelo, G., Gitau, G.K., Kamunde, C., Uehlinger, F. and Wichtel, J. (2015) Associations of farm management practices with annual milk sales on smallholder dairy farms in Kenya. Vet. World, Available from: http://www.veterinaryworld.org/Vol.8/ January-2015/18.pdf. Accessed on 09-08-2015.

40. KNBS, (Kenya National Bureau of Statistics). (2009) Kenya Population and Housing Census Report. Available from: https://www.international.ipums.org/international/ resources/enum_materials_pdf/enum_instruct_ke2009a. pdf. Accessed on 02-04-2015.

41. Mukurwe-ini Strategic Plan. (2012) Available from: http://www.Mukurwe-ini.net/userfiles/Mukurwe-ini/ Constituency/Strategic/Plan.pdf. Accessed on 26-02-2015.

42. Kabaka, W.M., Gitau, G. K., Kitala, P. M., Maingi, N. and Vanleeuwen, J. (2012) Risk factors associated with gastrointestinal nematode infections of cattle in Nakuru and Mukurwe-ini Districts of Kenya. Bull. Anim. Health Prod. Afr., 60: 413-419.

43. Clarke, S.C. and McIntyre, M. (2001) Acid-fast bodies in fecal smears stained by the modified Ziehl-Neelsen technique. Br. J. Biomed. Sci., 58(1): 7-10.

44. Soulsby, E.J.L. (1982) Helminths, Arthropods and Protozoa of Domesticated Animals. $7^{\text {th }}$ ed. Bailliere Tindall, London. p787-792.

45. PFukenyi, D.M., Mukaratirwa, S., Willingham, A.L. and Monrad, J. (2007) Epidemiological studies of parasitic gastrointestinal nematodes, cestodes and coccidian infections in cattle in the highveld and lowveld communal grazing areas of Zimbabwe. Onderstepoort J. Vet., 74: 129-142.

46. Cheesbrough, M. (1981) Medical Manual for Tropical Countries. $1^{\text {st }}$ ed., Vol. 1. Printed by Stephen Austin and Sons, London.

47. Microsoft Corporation. (2010) Available from: https://www. products.office.com/en-us/Excel. Accessed on 26-3-2015.

48. Wymann, M.N. (2005) Calf mortality and parasitism in peri-urban livestock production in Mali. PhD Thesis. Dissertation. University of Basel, Germany. Available from: http://www.edoc.unibas.ch/281/1/DissB_7204.pdf. Accessed on 20-2-2015).

49. Tizard, I.R. (2009) Veterinary Immunology. An Introduction. $8^{\text {th }}$ ed. Saunders Company, Philadelphia, PA. p224-238.

50. Xiao, L. and Herd, R.P. (1994) Infection pattern of Cryptosporidium and Giardia in calves. Vet. Parasitol., 55: $257-262$.

51. Thompson, J., Yank, R. and Power, M. (2008) Identification of zoonotic Giardia genotypes in masupials in Australia. Exp. Parasitol., 120: 88-93.

52. Hunter, P.R. and Thompson, R.C. (2005) The zoonotic transmission of Giardia and Cryptosporidium. Int. J. Parasitol., 35: 1181-1190.

53. Thompson, R.C.A. and Smith, A. (2011) Zoonotic enteric protozoa. Vet. Parasitol., 182: 70-78.

54. Abebe, R., Wossene, A. and Kumsa, B. (2008) Epidemiology of Eimeria infections in calves in Addis Ababa and Debre Zeit dairy farms, Ethiopia. Int. J. Appl. Res. Vet. M., 6: 24-30.

55. Priti, M., Sinha, S.R.P., Sucheta, S., Verma, S.B., Sharma, S.K. and Mandal, K.G. (2008) Prevalence of bovine coccidiosis at Patna. Vet. Parasitol., 22: 5-12.

56. Lassen, B. (2009) Diagnosis, epidemiology and control of bovine coccidiosis in Estonia. $\mathrm{PhD}$ Thesis. Estonian University of Life Sciences. Tartu.

57. Rehman, T.U., Khan, M.N., Sajid, M.S., Abbas, R.Z., Arshad, M., Iqbal, Z. and Iqbal, A. (2011) Epidemiology of Eimeria and associated risk factors in cattle of District Toba Tek Singh. Pak. Parasitol. Res., 108: 1171-1177.

58. Munyua, W.K. and Ngotho, J.W. (1990) Prevalence of Eimeria species in cattle in Kenya. Vet. Parasitol., 35: 163-168.

59. Dawid, F., Amede, Y. and Bekele, M. (2012) Calf coccidiosis in selected dairy farms of dire Dawa, Eastern Ethiopia. Glob. Vet., 9(4): 460-464.

60. Alemayehu, A., Nuru, M. and Belina, T. (2013) Prevalence of bovine coccidia in Kombolcha district of South Wollo, Ethiop. J. Vet. Med. Anim. Health, 5(2): 41-45.

61. Gül, A., Ciçek, M. and Kilinç, O. (2008) Prevalence of Eimeria species, Cryptosporidium species and Giardia species in calves in the van province. Turk. J. Parasitol., 32(3): 202-204.

62. McAllister, M.M. (2006) Protozoosis of the calf: Giardia, Cryptosporidium, Eimeria, Sarcocystis and Neospora. Proceedings of the $14^{\text {th }}$ World Buiatrics Congress, Nice, France.

63. DelCoco, V.F., Córdoba, M.A. and Basualdo, J.A. (2008) Cryptosporidium infection in calves from a rural area of Buenos Aires, Argentina. Vet. Parasitol., 158(1-2): 31-35.

64. Castro-Hermida, J.A., González-Losada, Y.A. and AresMazás, E. (2002) Prevalence of and risk factors involved in the spread of neonatal bovine cryptosporidiosis in Galicia (NW Spain). Vet. Parasitol., 106(1): 1-10.

65. Ramirez, N.E., Ward, L.A. and Sreevatsan, S. (2004) A review of the biology and epidemiology of cryptosporidiosis in humans and animals. Microbes. Infect., 6(8): 773-785.

66. Gow, S. and Waldner, C. (2006) An examination of the prevalence of and risk factors for shedding of Cryptosporidium species and Giardia species in cows and calves from western. Canadian cow-calf herds. Vet. Parasitol., 137(1-2): 50-61.

67. Nizeyi, J., Cranfield, M. and Graczyk, T. (2002) Cattle near the Bwindi Impenetrable National Park, Uganda, as a reservoir of Cryptosporidium parvum and Giardia duodenalis for local community and free-ranging gorillas. Parasitol. Res., 88(4): 380-385.

68. Ouchene, N., Ouchene-Khelifi, N.A., Zeroual, F., Benakhla, A. and Adjou, K. (2004) Study of Giardia spp., Cryptosporidium spp. and Eimeria spp. infections in dairy cattle in Algeria. J. Parasitol. Vector Biol., 6(4): 61-65.

69. Soltane, R., Guyot, K., Dei-Cas, E. and Ayadi, A. (2007) Cryptosporidium parvum (Eucoccidiorida: Cryptosporiidae) in calves: Results of a longitudinal study in a dairy farm in Sfax, Tunisia. Ucla. Sym. Bi., 14(4): 309-312.

70. Maldonado-Camargo,S.,Atwill,E.R., Saltijeral-Oaxaca,J.A. and Herrera-Alonso, L. (1998) Prevalence of and risk factors for shedding of Cryptosporidium parvum in Holstein Friesian dairy calves in central México. Prev. Vet. Med., 36(2): 95-107.

71. Coklin, T., Farber, J., Parrington, L. and Dixon, B. (2007) Prevalence and molecular characterization of Giardia duodenalis and Cryptosporidium species in dairy cattle in Ontario, Canada. Vet. Parasitol., 150(4): 297-305.

72. Trotz-Williams, L.A., Wayne, S.M., Kenneth, E.L., Todd, D., Daryl, V.N. and Peregrine, A.S. (2008) Association between management practices and within-herd prevalence of Cryptosporidium parvum shedding on dairy farms in southern Ontario. Prev. Vet. Med., 83(1): 11-23.

73. El-Shazly, A.M., Gabr, A., Mahmoud, M.S.E., Aziz, S.S.A. and Saleh, W.A. (2002) The use of Ziehl-Neelsen stain, enzyme-linked immunosorbent assay and nested polymerase chain reaction in diagnosis of cryptosporidiosis in immuno-competent - compromised patients. J. Egypt. Soc. Parasitol., 32(1): 155-166.

74. O'Handley, R.M., Cockwill, C., McAllister, T.A., 
Jelinski, M., Morck, D.W. and Olson, M.E. (1999) Duration of naturally acquired giardiasis and cryptosporidiosis in dairy calves and their association with diarrhea. J. Am. Vet. Med. Assoc., 214: 391-396.

75. Singh, B.B., Sharma, R., Kumar, H., Banga, H.S., Aulakh, R.S., Gill, J.P.S. and Sharma, J.K. (2006) Prevalence of Cryptosporidium parvum infection in Punjab (India) and its association with diarrhea in neonatal dairy calves. Vet. Parasitolo., 140: 162-165.

76. Maddox-Hyttel, C., Langkjaer, R.B., Enermark, H.L. and Vigre, H. (2006) Cryptosporidium and Giardia in different age groups of Danish cattle and pigs-occurrence and management associated risk factors. Vet. Parasitol., 141(1-2): 48-59.

77. Kulišić, Z., Aleksi, N., Orvevi, M., Gaji, B. and Tambur, Z. (2012) Prevalence of gastrointestinal helminths in calves in Western Serbia. Acta. Vet. Beograd., 62(5-6): 665-673.

78. Pfukenyi, D.M. and Mukaratirwa, S. (2013) A review of the epidemiology and control of gastrointestinal nematode infections in cattle in Zimbabwe. Onderstepoort. J. Vet., 80(1): 12. Available from: http://www.dx.doi. org/10.4102/ ojvr.v80i1.612. Accessed on 29-3-2015.
79. Lima, W.S. (1998) Seasonal infection pattern of gastrointestinal nematodes of beef cattle in minas Gerais State, Brazil. Vet. Parasitol., 74: 203-214.

80. Wade, W.E., Mohammed, H.O. and Schaaf, S.L. (2000) Prevalence of Giardia species, Cryptosporidium parva and Cryptosporidium murius (C. andersoni) in 109 dairy herds in five counties of southeastern New York. Vet. Parasitol., 93: 1-11

81. Trout, J.M., Santrin, M., Greiner, E. and Faver, R. (2004) Prevalence of Giardia duodenalis genotypes in pre-weaned dairy calves. Vet. Parasitol., 124 (3-4): 179-186.

82. Ralston, B.J., McAllister, T.A. and Olson, M.E. (2003) Prevalence and infection pattern of naturally acquired giardiasis and cryptosporidiosis in range beef calves and their dams. Vet. Parasitol., 114: 113-122.

83. Davoudi, Y., Garedaghi, Y. and Safarmashaei, S. (2011) Epidemiology of giardiasis in diarrheic calves in EastAzerbaijan Province, Iran. J. Anim. Vet. Adv., 10(19): 2508-2510.

84. Slapeta, J. (2007) Cryptosporidium species found in cattle: A proposal for a new species. Trends Parasitol., 22: 469-474. 